\title{
Formation of the introduced coenopopulation of Crocus reticulatus on the botanical-geographical plot "Steppes of Ukraine" at the M. M. Gryshko National Botanical Garden of the NAS of Ukraine
}

\author{
(ㄱ) Victoria Gritsenko
}

M.M. Gryshko National Botanical Garden, National Academy of Sciences of Ukraine, Tymiryazevska str. 1, 01014 Kyiv, Ukraine; gritsenkoviktoria@gmail.com

Received: 27.10 .2020 | Accepted: 25.12 .2020 | Published: 30.12 .2020

\begin{abstract}
The research was carried out during Crocus reticulatus flowering time in 2002-2020 at the botanicalgeographical plot "Steppes of Ukraine" of the M.M. Gryshko National Botanical Garden, National Academy of Sciences of Ukraine (NBG). Crocus reticulatus was introduced to the NBG from the natural habitats in 2002-2003. Ten generative individuals were planted in an area of $2 \mathrm{~m}^{2}$. The area of coenopopulation and the number of individuals increased gradually until 2018. In 2019-2020, there was a rapid increase in the covered area and number of individuals. However, the average density of individuals decreased. The percentage of pregenerative plants (juvenile, immature, and virginal) increased, and the percentage of generative individuals decreased. As of 2020, the area of introduced coenopopulation of $C$. reticulatus at the NBG reached $195 \mathrm{~m}^{2}$. It consists of 175 individuals (38 juvenile, 21 immature, 23 virginal, and 93 generative). The average density is 0.9 individuals per $1 \mathrm{~m}^{2}$. The spatial distribution of individuals is characterized as random and in groups. This is due to the predominance of the myrmecochoric and barochoric propagation. Indicators of the area, number, and average density of the introduced coenopopulation are within the normal ranges of the natural populations; however, they are smaller than those in maternal populations. The number of individuals of different age states and the number of individuals with one and two or three flowers in the introduced coenopopulation is close to such parameters of the natural population from Kyiv Plateau. Flowers of different colors were observed both in the introduced coenopopulation and in natural populations of $C$. reticulatus. As of 2020, the introduced coenopopulation of $C$. reticulatus is in the phase of logistic growth.
\end{abstract}

Keywords: Crocus reticulatus, introduced coenopopulation, logistic growth, ex situ protection

\section{Introduction}

Crocus reticulatus Steven ex Adam (Iridaceae Juss.) is a sub-Mediterranean-Asia Minor species on the north-eastern border of the range, listed in the Red Book of Ukraine under the 'not evaluated' status (Korotchenko \& Peregrym, 2009). This species is distributed in Central Europe, the Mediterranean, the Ciscaucasia, the northern part of the Western Caucasus, and Asia Minor. In Ukraine, the species is common in the Right Bank and Left Bank Forest-Steppe. It also rarely occurs in the Steppe zone of Ukraine (Sobko et al., 2013).

Systematic position, distribution, ecological and coenotic peculiarities, as well as the ontogenesis, state of natural populations, morphological parameters, and aspects of in situ protection of $C$. reticulatus were intensively investigated (Dirdovskiy, 1931; Fomin \& Bordzilovsky, 1950; Burda et al., 1995; Kucherevsky, 2001; Ostapko, 2001; 

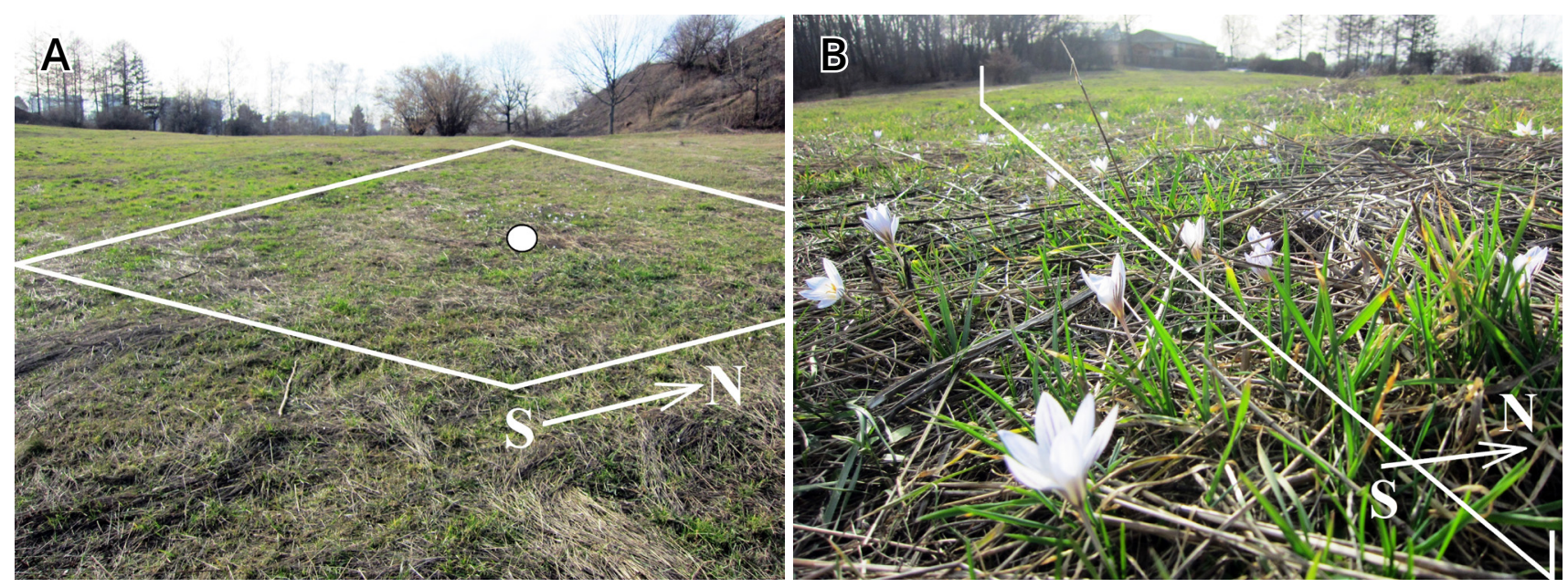

Figure 1. The introduced coenopopulation of Crocus reticulatus on the botanical-geographical plot "Steppes of Ukraine" at the M.M. Gryshko National Botanical Garden of the NAS of Ukraine, March 2020: A - general view (white point indicates the coordinates centroid); B - the fragment. Scale: A - 10×10 m; B - 5 m.

Gritsenko, 2004, 2007; Peregrym, 2004; Bayrak \& Stetsyuk, 2005; Bayrak et al., 2006; Krivoruchko, 2006, 2008; Shynder, 2009, 2010; Melnyk et al., 2010; Orlova \& Boboshko, 2012; Kushnir, 2015; Dakieva et al., 2017; Shilova et al., 2019; Cherniavskih \& Glubscheva, 2020; Vladimirov et al., 2020). Based on the molecular analysis, Harpke et al. (2014) revealed that C. reticulatus is not an integral species but represents an aggregate. Comparative analysis of the morphological and leaf anatomical characters of two species from this aggregate has been recently presented by Ljubisavljević \& Raca (2020).

The introduction of plants listed in the Red Book of Ukraine is an important aspect of their ex situ protection (Melnyk et al., 2018). Crocus reticulatus is an ornamental herbaceous plant, early spring ephemeroid growing in culture and semi-natural conditions in many botanical gardens and arboretums of Ukraine (Mashkovska, 2015). In particular, C. reticulatus was introduced to the botanical-geographical plots "Steppes of Ukraine", "Caucasus", and "Rare plants of the Ukrainian flora" of the M.M. Gryshko National Botanical Garden, National Academy of Sciences of Ukraine (NBG) (Gritsenko, 2009; Kushnir, 2014; Gritsenko et al., 2017). Simultaneously, Pavlova \& Kachur (2012) studied the introduction of the genus Crocus (including C. reticulatus) in the Donetsk Botanical Garden, National Academy of Sciences of Ukraine.

Experimental data and mathematical models are widely applied to describe the populations (Didukh, 1998; Rassadina \&
Antonova, 2015; Ibragimova et al., 2017). Experimental studies of introduced populations of several rare plant species were conducted at the NBG before (Gritsenko, 2007, 2014, 2017a, 2019a; Didenko, 2016; Gaponenko \& Gnatiuk, 2016). Melnyk et al. (2018) proposed a new method of protection of floral diversity ex situ by modeling introductory populations in forest and steppe cultural phytocoenoses. Kushnir $(2015,2019)$ studied the morphology of the fruits, seeds, pollen grains, and leaves of C. reticulatus basing on the NBG material.

In recent years, a rapid increase in the number of individuals and the covering area of $C$. reticulatus coenopopulation on the botanical-geographical plot "Steppes of Ukraine" at the NBG has been registered (Gritsenko, 2019b). Hence, there was a strong practical and theoretical need to investigate this coenopopulation with the purposes of introduction and ex situ conservation of C. reticulatus and compare it with natural populations.

\section{Material and methods}

The studies were conducted in 2002-2020 during $C$. reticulatus flowering time. The material for introduction in sets of five generative individuals was provided from its natural populations from the Donetsk Upland (by M. Peregrym in 2002) and the Kyiv Plateau (by V. Gritsenko in 2003). Plants were planted randomly on an area of $1.0 \times 2.0 \mathrm{~m}$ $(\mathrm{S} \rightarrow \mathrm{N})$, becoming an initial diaspores source. 

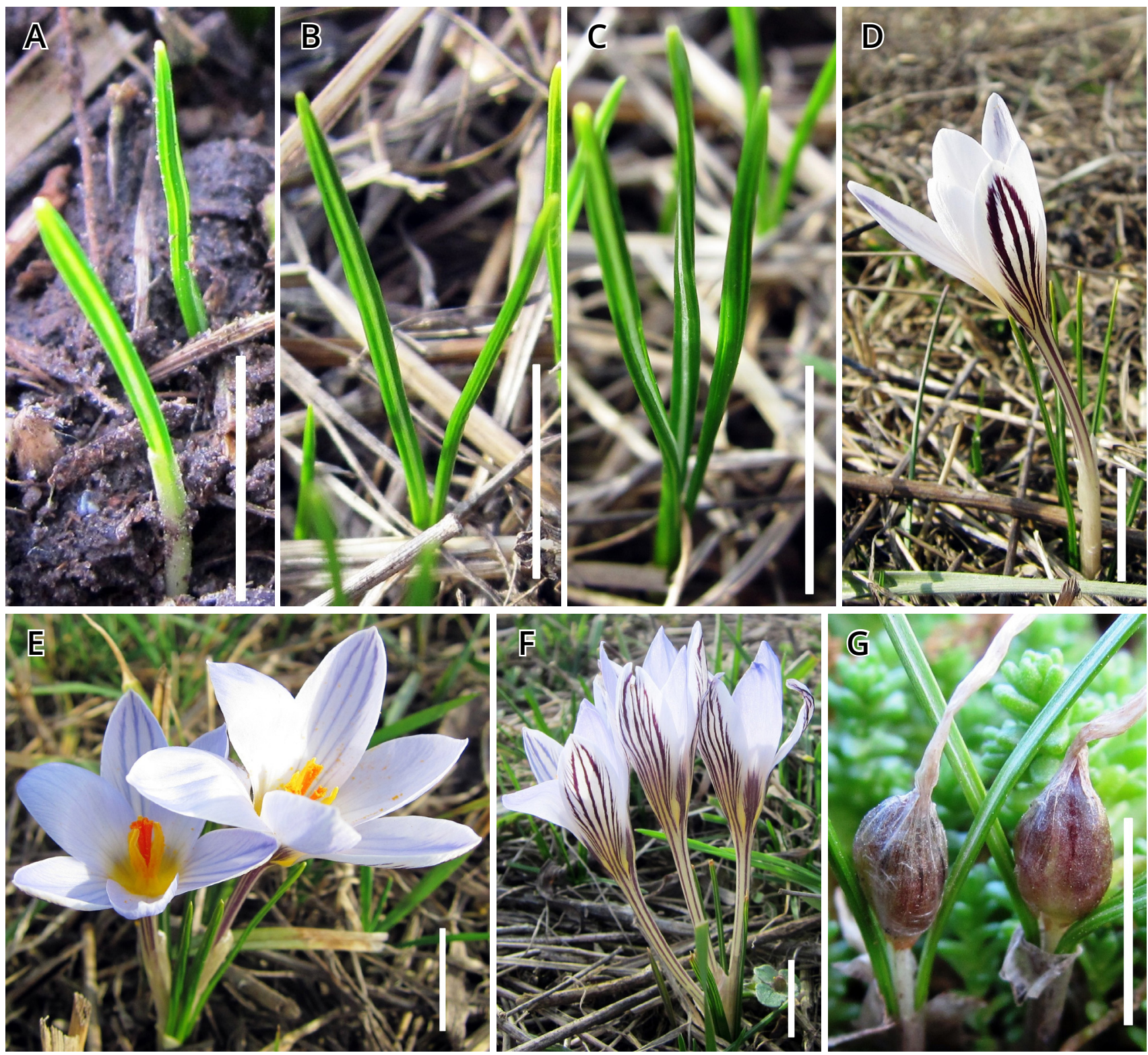

Figure 2. Crocus reticulatus individuals: A - juvenile; B - immature; C - virginal; D-G - generative with one $(D)$, two $(E)$, and three flowers $(F)$, and with fruits $(G)$. Scale $=2 \mathrm{~cm}$.

Single C. reticulatus individuals brought later (Gritsenko, 2014) were planted in the nursery. These individuals did not participate in the formation of the introduced coenopopulation of the species. The introduced coenopopulation of C. reticulatus is located in the eastern part of the botanical-geographical plot "Steppes of Ukraine" $\left(50.411978^{\circ} \mathrm{N}, 30.566114^{\circ} \mathrm{E}\right)$ of the NBG (Fig. 1).

The NBG introduction plot was selected as the most similar to the natural habitat in the Kyiv region (mostly on the slopes of southern exposition). However, it is characterized by a slight inclination of the surface (about $10^{\circ}$ ) in the south-eastern direction. Due to the slightly different slope exposition, the indicators of the thermal regimes of soil and air in the experimental plot at the NBG are only slightly higher.

The area of the introduced coenopopulation of C. reticulatus was measured every year using measuring tape and rounded with a precision of $1 \mathrm{~m}^{2}$. The plants were neither damaged nor excavated during the research. The age states of $C$. reticulatus were determined by analysis of the aboveground parts of the plants (Gritsenko, 2004, 2007). The number of generative individuals was being defined annually. The number of individuals of all age states (juvenile, immature, virginal, and generative) was checked in 2009, 2014, 2019, and 2020. During these years, a significant 


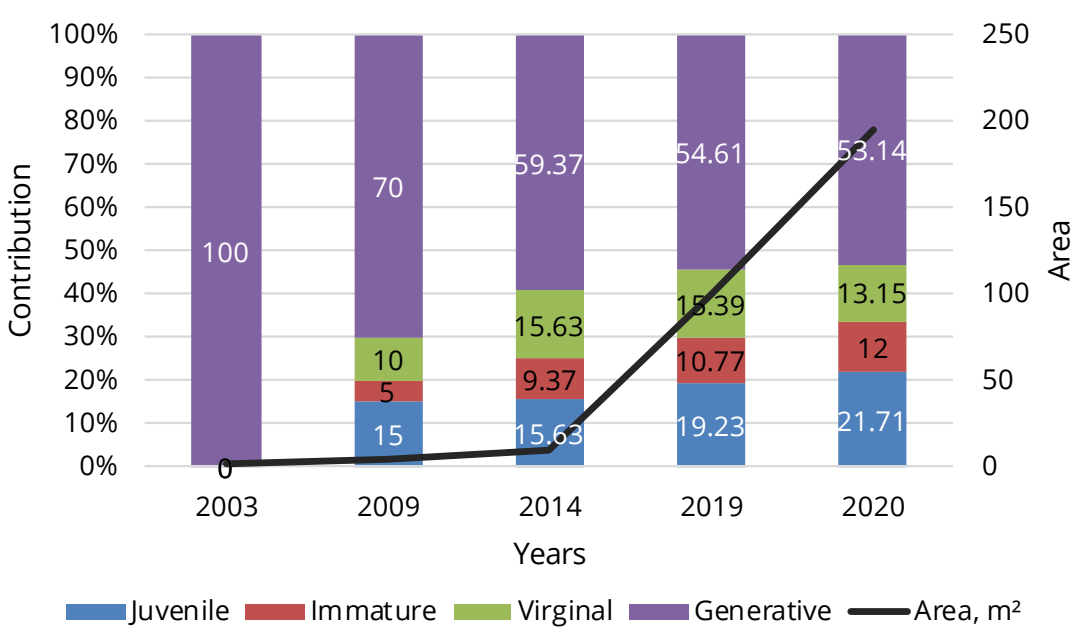

Figure 3. Dynamics of age structure and area of Crocus reticulatus introduced coenopopulation in the years of detailed research.

increase in the number of individuals was observed. The study of the coenopopulation structure was conducted according to Uranov (1976). When mapping the spatial location of generative individuals, the area of the coenopopulation was divided into $1 \times 1 \mathrm{~m}$ plots, using cords and tape measure. The arithmetic mean was calculated following Lakin (1990). Deviations of the author's original data from the data published in the literature were calculated by the following formula:

Dev. $=100-\mathrm{y} \times 100 / \mathrm{x}$,

where

$\mathrm{x}$ - original data,

$\mathrm{y}$ - literature data.

Plant names are provided according to The Plant List (2020). Species were determined following Prokudin (1987). All photos were captured using a Canon Power Shot SD 4000 IS Digital ELPH camera.

\section{Results and discussion}

\section{Area of the introduced population}

The area of $C$. reticulatus introduction at the NBG is characterized by the absence of trees and shrubs (Fig. 1). Crocus reticulatus grows there in the composition of meadowsteppe cultural phytocoenosis, which is characterized by considerable taxonomic diversity (Gritsenko, 2017b). During the flowering time of C. reticulatus (in March), the early spring synusia comprise Ficaria verna Huds., Gagea pusilla (F.W. Schmidt) Sweet, and Scilla siberica Haw. The soil surface is covered with a dense, $2-5 \mathrm{~cm}$ thick layer of litter from the remains of various plants of the previous year. The height of the grass stand reaches $20 \mathrm{~cm}$, and its projective cover $-70 \%$. After a fruiting time (in the second half of May), the aboveground parts of $C$. reticulatus dry up and die. Then, due to the growth and development of cereals (Elymus hispidus (Opiz) Melderis, E. repens (L.) Gould, Festuca valesiaca Schleich. ex Gaudin, Poa angustifolia L., etc.) and motley grasses in May, the height of the grass stand can exceed $1 \mathrm{~m}$, and its total projective cover can reach $100 \%$. Therefore, the conditions of this meadow-steppe cultural phytocoenosis are similar to natural ones.

\section{Ontogenetic aspect}

Several generations of introduced C. reticulatus were formed at the botanicalgeographical plot "Steppes of Ukraine" until 2020. During flowering time (in March), juvenile, immature, virginal, and generative individuals (Fig. 2) were observed too. Among the generative individuals, the most frequent were those with one flower $(65$ such individuals were observed in 2019, and 77 in 2020; Fig. 3). Plants with two flowers were not widely spread (six such individuals were observed in 2019, and 14 - in 2020; Fig. 2 E), while those of three flowers were very rare (none such individuals were observed in 2019, and only two plants - in 2020; Fig. 2 F). Fruit ripening (Fig. 2 G) and seed dispersion occur in May. The seeds germinate in the fall of the same year (Gritsenko, 2004, 2007). It takes five-seven years for $C$. reticulatus to reach the generative state. In the generative state, its individuals can exist for more than 


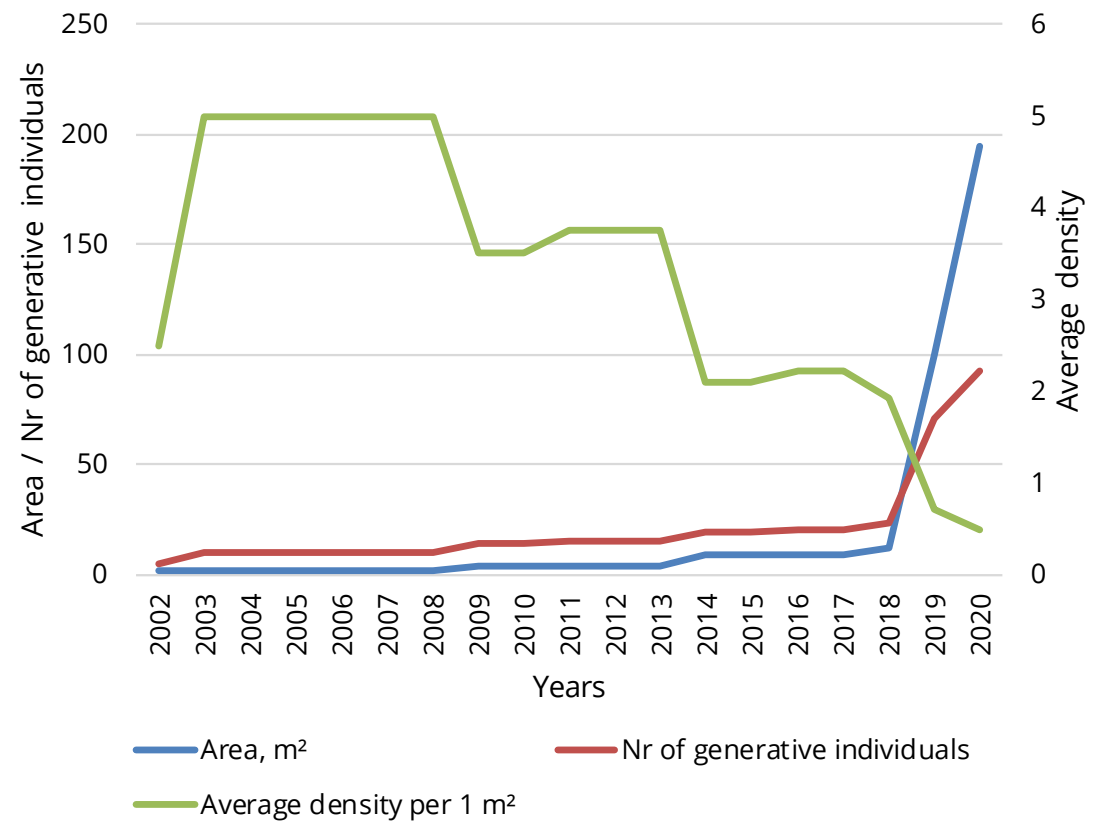

Figure 4. Dynamics of area, number of generative individuals, and average density in Crocus reticulatus introduced coenopopulation. ten years. Hence, senile individuals at the experimental plot at the NBG have not been found.

In the spectra of age states (in 2009-2020), the percentage of pregenerative individuals of ontogenesis (juvenile, immature, and virginal) increased, and the percentage of generative individuals decreased (Fig. 3).

\section{Number and density of generative individuals}

In 2003, due to the continued introduction of generative individuals, their number and average density doubled (Fig. 4). After completing the introduction, in 2003-2008, the coenopopulation area, the number, and the average density of generative individuals did not change. In 2009-2018, the coenopopulation area and the total number of generative individuals gradually increased; however, the average density of generative individuals decreased (Fig. 4). In 2019-2020, there was a rapid increase in the coverage area and the number of individuals (Fig. 4).

In 2020, the area of introduced coenopopulation of $\mathrm{C}$. reticulatus reached $195 \mathrm{~m}^{2}$ and comprised 93 generative individuals. The average density of the generative individuals reached 0.48 per $1 \mathrm{~m}^{2}$. Hence, from 2003 to 2020, the area occupied by $C$. reticulatus increased 97.5 times, and the number of generative individuals increased 9.3 times.

\section{Number and density of individuals belonging to different ontogenetic stages}

In 2003, only generative introduced C. reticulatus individuals were available in the botanical-geographical plot "Steppes of Ukraine" (Fig. 3). Over time, plants of the new generations appeared. From 2003 till 2020, the total number of juvenile, immature, virginal, and generative individuals increased 17.5 times, but their average density decreased (Fig. 4). As of 2020, the introduced coenopopulation of $C$. reticulatus consisted of 175 individuals (38 juvenile, 21 immature, 23 virginal, and 93 generative), and their average density reached 0.9 individuals per $1 \mathrm{~m}^{2}$.

\section{Development trends of introduced coenopopulation}

Obtained graph (Fig. 4) illustrates the initial phase of logistic growth (Ricklefs, 1979; Rassadina \& Antonova, 2015) of C. reticulatus introduced coenopopulation. The dynamics of these parameters indicate the tendency to further increase in the area and number of individuals and stable positions of this species in the investigated meadow-steppe cultural phytocoenosis. This confirms the successful reproduction and settlement of $\mathrm{C}$. reticulatus on the botanical-geographical plot "Steppes of Ukraine". However, in other plots of the NBG ("Caucasus" and "Rare plants of the Ukrainian flora"), such rapid growth of C. reticulatus coenopopulations was not observed. 
A
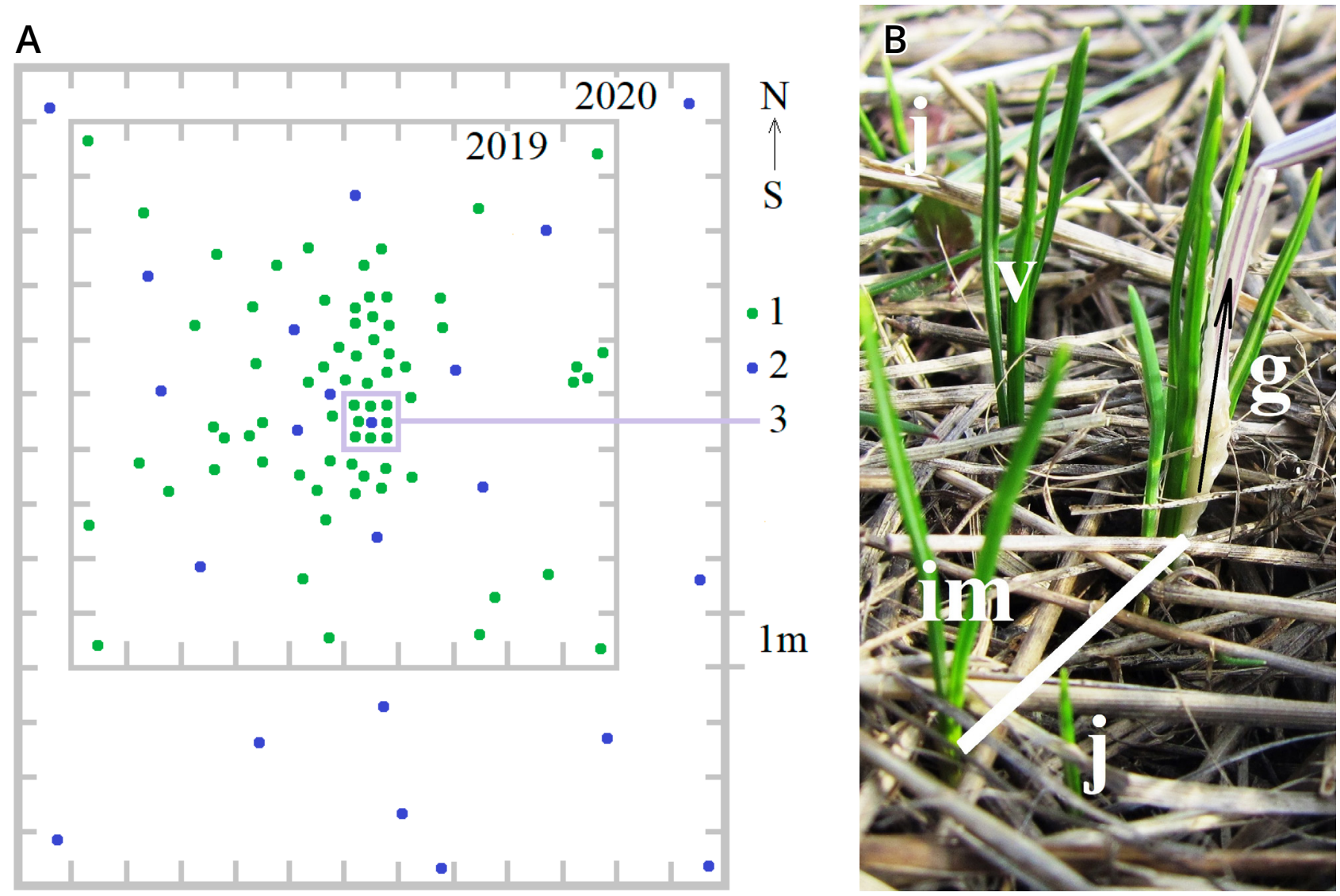

Figure 5. Spatial distribution of Crocus reticulatus individuals in the introduced coenopopulation: A - quantity dynamics of generative individuals existed in 2019 (1) and newly appeared in 2020 (2), and the fragment with the maximum density of generative individuals (3); B - individuals of different age states ( $\mathbf{j}$ - juvenile, im - immature, $\mathbf{v}$ - virginal, $\mathrm{g}$ - generative; arrow indicates perianth tube; scale $=4 \mathrm{~cm}$ ).

\section{Spatial distribution and dissemination modes}

The spatial distribution of individuals in the introduced coenopopulation of C. reticulatus is random and grouped. Single individuals of different age states are distributed at the coenopopulation edges and in its central part. On the other hand, groups of individuals of different age states occur in the central part of the coenopopulation because of the predominance of seed propagation and different dissemination modes.

Cherniavskih \& Glubscheva (2020) found that the location and number of C. reticulatus individuals with white flowers in the population are random and probably resulted from myrmecochory. We observed the appearance of new single individuals, particularly generative ones (Fig. $5 \mathrm{~A}$ ), at a distance of several meters from the previously existing generative individuals, which may result from myrmecochory. From the other side, some pregenerative individuals were located just near the maternal generative individual (Fig. 5 B), which evidenced the barochory.

The dynamics of the spatial distribution of C. reticulatus in 2019-2020 illustrates the increase in the area and number and the decrease in the density of generative individuals at the edges of the coenopopulation (Fig. $5 \mathrm{~A}$ ). This reflects general reduction of the average density of generative individuals (Fig. 4). Their much lower number at the edges of the coenopopulation also explains the decrease in the average density of all individuals. Hence, with the increase of $C$. reticulatus population area, the density of individuals on its margins progressively decreases.

\section{Flower coloration}

Vladimirov et al. (2020) separated eight morphotypes of $C$. reticulatus with the differently colored perianth. Crocus reticulatus plants with light violet (Fig. 2 E-F; Fig. 6 A), light blue (Fig. 6 B), and white (Fig. 2 D; Fig. 6 C) flowers are present in the investigated 

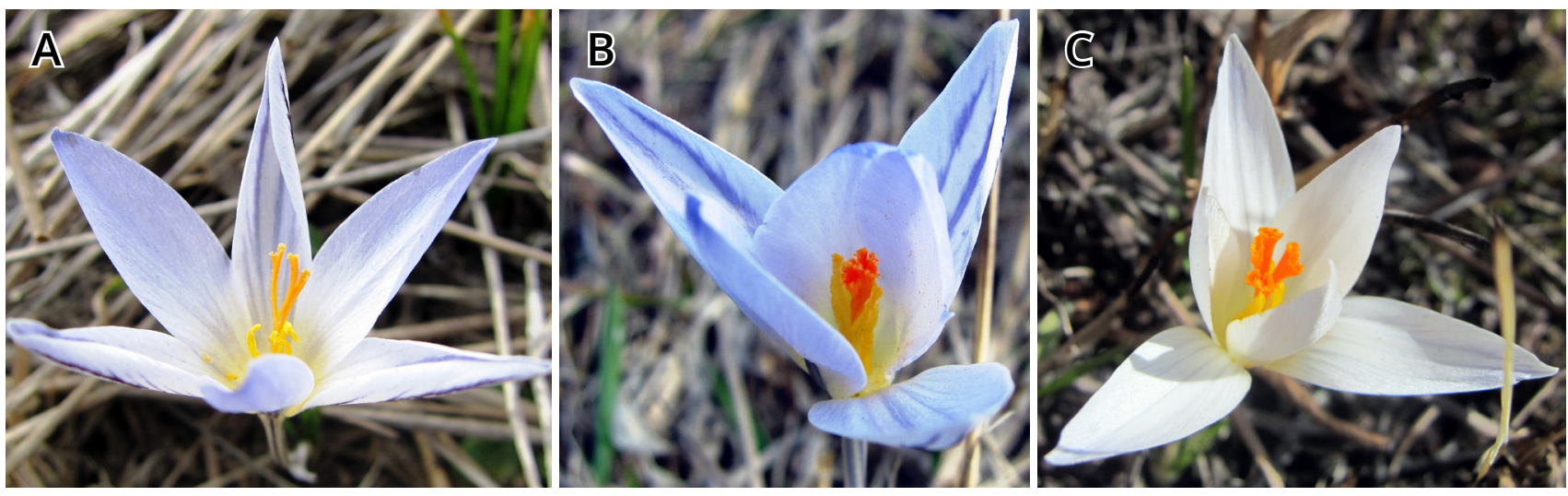

Figure 6. Crocus reticulatus with flowers of different coloration: A - light violet; B - light blue; C - white.

coenopopulation at the NBG. All flowers have dark violet stripes on the outside of the perigone segments. If an individual has several flowers, they all have the same coloration (Fig. 2 E-F). Flowers of different colors were also observed in the species' natural populations (Korotchenko \& Peregrym, 2009; Cherniavskih \& Glubscheva, 2020; Vladimirov et al., 2020).

\section{Comparison of obtained data with the results from relevant sources}

The parameters of the introduced coenopopulation of $\mathrm{C}$. reticulatus were compared with the corresponding parameters of the natural populations of this species. Natural populations of $C$. reticulatus are characterized by wide ranges of the covering area (from thousands of a hectare up to dozens of hectares), the number of individuals (from tens to hundreds of thousands of individuals), and the average density of individuals (from 0.1 to tens of individuals per $1 \mathrm{~m}^{2}$ ) (Gritsenko,
2004; Peregrym, 2004; Korotchenko \& Peregrym, 2009; Shynder, 2009, 2010; Melnyk et al., 2010; Shilova et al., 2019; Cherniavskih \& Glubscheva, 2020; Vladimirov et al., 2020). Hence, the introduced coenopopulation of C. reticulatus from the NBG is completely framed within these wide ranges. The natural population of $C$. reticulatus with the similar small area, number, and average density of individuals was reported from Voronezh region (Shilova et al., 2019). However, if compared with original natural populations from the Kyiv Plateau and Donetsk Upland, the introduced coenopopulation at the NBG is characterized by significantly lower area, number, and average density of individuals (Table 1).

By the number of individuals of different age states, the introduced coenopopulation is closer to the natural population on the Kyiv Plateau (variation range is from $-30.77 \%$ to $+33.33 \%$ ) and differs from Donetsk Upland natural populations (variation range is from $-91.67 \%$ to $+28.57 \%$ ) (Fig. 7 ).

Table 1. Comparison of introduced coenopopulation and natural populations of Crocus reticulatus.

\begin{tabular}{|c|c|c|c|c|}
\hline \multirow[b]{2}{*}{ Parameters } & \multirow[b]{2}{*}{$\begin{array}{l}\text { Introduced } \\
\text { coenopopulation. } \\
\text { NBG, } 2020\end{array}$} & \multicolumn{3}{|c|}{ Natural populations } \\
\hline & & $\begin{array}{l}\text { Kyiv Plateau } \\
\text { (Gritsenko, 2004) }\end{array}$ & $\begin{array}{l}\text { Donetsk Upland } \\
\text { (Peregrym, 2004; } \\
\text { Korotchenko \& } \\
\text { Peregrym, 2009) }\end{array}$ & $\begin{array}{l}\text { Voronezh region, } \\
\text { Russia (Shilova et al., } \\
\text { 2019) }\end{array}$ \\
\hline Area, hectares & 0.0195 & 8.0 & $2.0-45.0$ & 0.01 \\
\hline $\begin{array}{l}\text { Number of } \\
\text { individuals }\end{array}$ & 175 & 300,000 & Thousands & 100 \\
\hline $\begin{array}{l}\text { Average density of } \\
\text { individuals per } 1 \mathrm{~m}^{2}\end{array}$ & 0.9 & 4.0 & $13.0-15.0$ & 1.0 \\
\hline
\end{tabular}




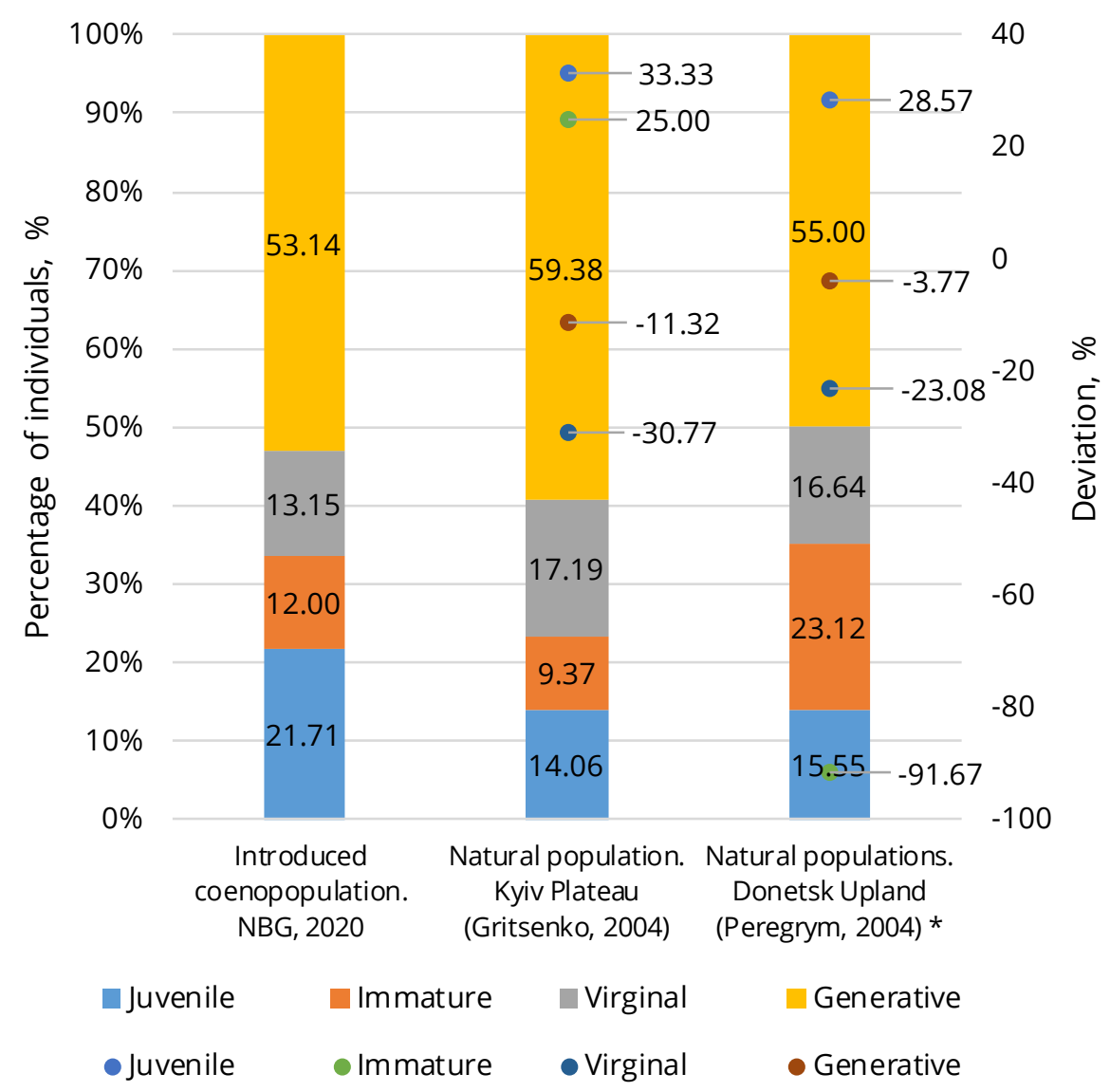

Figure 7. Number of individuals of different age stages in the introduced coenopopulation and natural populations of Crocus reticulatus. * - the arithmetic mean of ten natural populations has been taken.

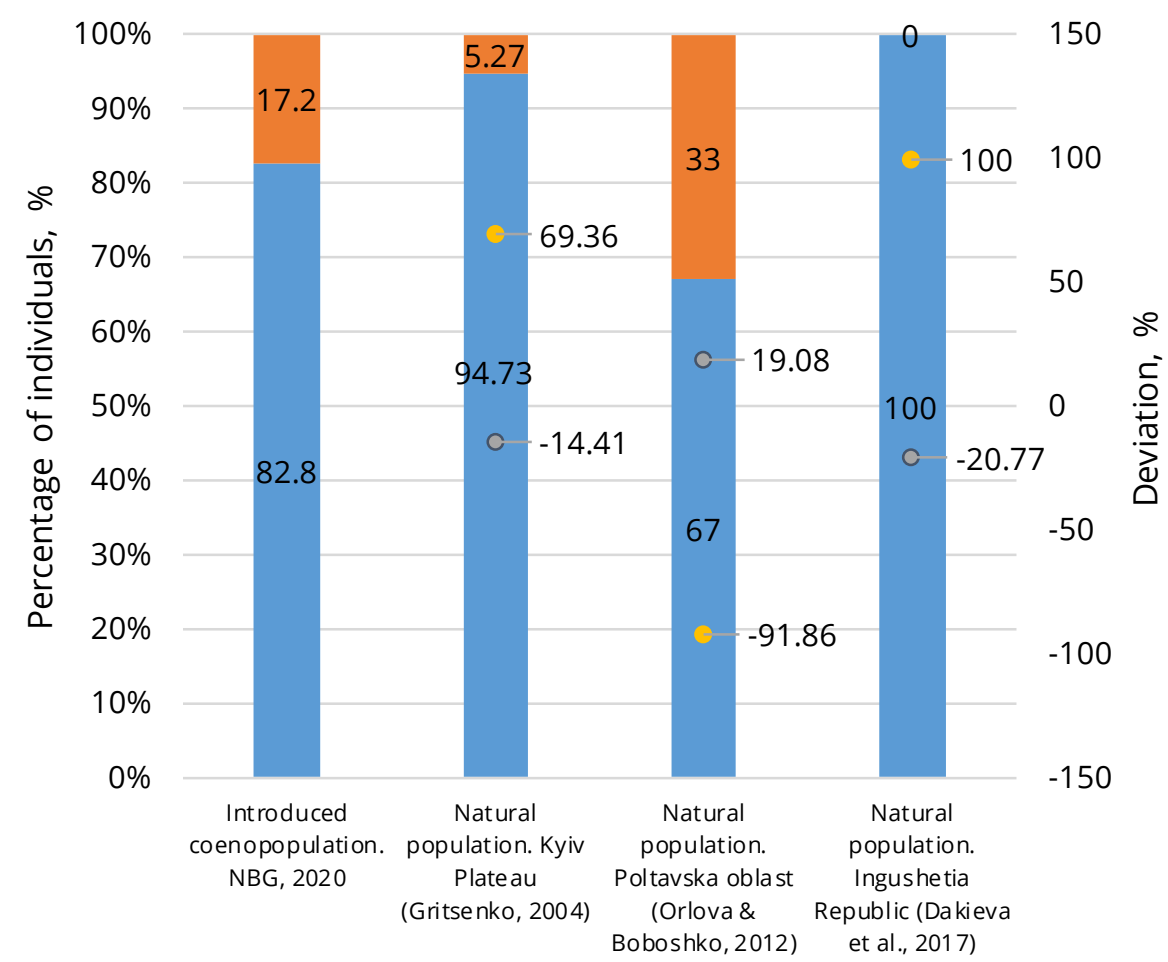

- One flower $\square$ Two or three flowers o One flower $\circ$ Two or three flowers

Figure 8. Variation of the flower number in the introduced coenopopulation and natural populations of Crocus reticulatus. 
The number of immature individuals in the natural and introduced populations is characterized by the most extensive range of variation, from $-91.67 \%$ to $+25.00 \%$. Simultaneously, juvenile, virginal, and generative individuals have much smaller ranges of variation (Fig. 7).

In the introduced coenopopulation and natural populations of the species, plants with a single flower predominate. The general variation of the number of individuals with one flower ranges only slightly. The variation of individuals with two or three flowers is much wider. Comparing the number of flowers per plant, the introduced coenopopulation of $\mathrm{C}$. reticulatus is also closer to the natural population on the Kyiv Plateau (Fig. 8).

\section{Conclusions}

As of 2020, the introduced coenopopulation of $C$. reticulatus at the NBG is in the phase of logistic growth. Thus, it tends to increase the area and number of individuals. Its parameters lay within the frames inherent to the natural populations. The conducted research testifies its successful formation in the meadowsteppe cultural phytocoenosis of the NBG. Hence, this introduced coenopopulation can be considered a model of $C$. reticulatus natural population.

\section{References}

Bayrak, O. M., \& Stetsyuk, N. O. (2005). Atlas of rare and endangered plants of Poltava region. Poltava: Verstka. (In Ukrainian)

Bayrak, O. M., Shevel, I. M., Gritsay, I. A., Krivoruchko T. V., \& Nechitaylo, V. I. (2006). Drabinivka Botanical Reserve. Poltava: Verstka. (In Ukrainian)

Burda, R. I., Ostapko, V. M., \& Larin, D., A. (1995). Atlas of protected plants (species of flora of southeastern Ukraine, listed in the Red Book). Kyiv: Naukova Dumka. (In Russian)

Cherniavskih, V. I., \& Glubscheva, T. N. (2020). About some features of the ability of flowering specials Crocus reticulatus in various elements of the mesorelief of beams in the southern of the Middle Russian hill. Field Biologist Journal, 2(2), 147-163. (In Russian)
Dakieva, M. K., Khashieva, L. S., \& Bekbotova, C. S. (2017). Ecological and biological features of Crocus reticulatus (Iridaceae) in the Republic of Ingushetia. Botanical Herald of the North Caucasus, 1, 5-10. (In Russian). Retrieved from http:// gorbotsad.ru/files/Dakieva-et-al..pdf

Didenko, S. Y. (2016). Evaluation of introduction of Caucasian flora species in conditions of M.M. Gryshko National Botanical Garden of the NAS of Ukraine. PlantIntroduction, 72, 14-21. (InUkrainian). https://doi.org/10.5281/zenodo.2457171

Didukh, Y. P. (1998). Population ecology. Kyiv: Phytosociocenter. (In Ukrainian)

Dirdovskiy, V. U. (1931). To the flora of Bila Tserkva region. Notes of the Masliv Institute of Breeding, 4, 127-141. (In Ukrainian)

Fomin, O. V., \& Bordzilovsky, E. I. (1950). Family Irysovi - Iridaceae Lindl. In M. I. Kotov (Ed.), Flora of UkrSSR. Vol. 3 (pp. 276-312). Kyiv: Edition of the Academy of Sciences of the UkrSSR. (In Ukrainian)

Gaponenko, M. B, \& Gnatiuk, A. M. (2016). Formation of introduction population of plants as a way for conservation the rarity flora fund. Bulletin of Botanical Garden-Institute, 15, 13-15. (In Russian). Retrieved from https://botsad.ru/media/cms/3615/13-15.pdf

Gritsenko, V. V. (2004). Crocus reticulatus Stev. ex Adam (Iridaceae) on the Kyiv Plateau. In J. K. Pachosky and modern botany (pp. 264-268). Kherson: Aylant. (In Ukrainian)

Gritsenko, V. V. (2007). The meadow steppes of the Kyiv plateau: Flora, vegetation, population of rare species and protection [PhD dissertation]. Kyiv. (In Ukrainian)

Gritsenko, V.V.(2009). The results of the introduction of plants in the botanical-geographic plot "Steppes of Ukraine" in M.M. Gryshko National Botanical Gardens of the NAS of Ukraine. Plant Introduction, 44, 18-24. (In Ukrainian). https://doi. org/10.5281/zenodo.2555365

Gritsenko, V. V. (2014). Introduced coenopopulations of the rare species of plants, brought in the Red Data Book of Ukraine, in steppe culturphytocoenose. Florology and Phytosozology, 3-4, 276-281. (In Ukrainian)

Gritsenko, V. V. (2017a, March 14-15). Experience of conservation and ex situ protection of plant species, listed in the Red Book of Ukraine, in the M.M. Gryshko National Botanical Garden, National Academy of Sciences of Ukraine on botanical-geographical plot "Steppes of Ukraine". In Proceedings of the All-Ukrainian scientific-practical conference "Affair of reserve in the Steppe zone of Ukraine". Ser. Conservation Biology in Ukraine, 2(2) (pp. 60-65). Kyiv. (In Ukrainian). Retrieved from http://uncg.org.ua/wp-content/uploads/2019/04/ UNCG22-Nadmorsky_T2.pdf 
Gritsenko, V. V. (2017b). Phytodiversity of the botanical-geographical section "Steppes of Ukraine" in the National Botanical Garden N.N. Grishko NAS of Ukraine. Forestry and Gardening, 12, 9558. (In Ukrainian). Retrieved from http://journals.nubip.edu.ua/index.php/ Lis/article/view/9558/

Gritsenko, V. V. (2019a). Evaluation of success of introduction of rare species of plants in the meadow-steppe culturphytocoenosis. Plant Introduction, 82, 24-33. (In Ukrainian). https://doi. org/10.5281/zenodo.3241019

Gritsenko, V. V. (2019b). Model of the meadow steppe of Ukraine: The plant and animal world. News of the Biosphere Reserve Askania Nova, 21, 308-318. (In Ukrainian). Retrieved from http:// askania-nova-zapovidnik.gov.ua/2020/02/21/ visti-biosfernogo-zapovidnika-askaniyanova-2019/

Gritsenko, V. V., Gnatiuk, A. N., \& Kushnir, N. V. (2017, June 6-8). The results of the introduction of rare species of steppe ephemeroids to the National Botanical garden of Ukraine. In Proceedings of the International Conference "Role of Botanical Gardens and Arboretums in conservation, investigation and sustainable using diversity of the plant world". Vol. 1 (pp. 63-66). Minsk. (In Russian). Retrieved from http://hbc.bas-net.by/hbcinfo/ books/ConfMinsk2017-part1.pdf

Harpke, D., Peruzzi, L., Kerndorff, H., Karamplianis, T., Constantinidis, T., Ranđelović, V., Randelović, N., Jušković, M., Pasche, E., \& Blattner, F. (2014). Phylogeny, geographic distribution, and new taxonomic circumscription of the Crocus reticulatus species group (Iridaceae). Turkish Journal of Botany, 38, 1182-1198. https://doi.org/10.3906/bot1405-60

Ibragimova, L. S., Yumagulov, M. G., Ishbirdin, A. R., \& Ishmuratova, M. M. (2017). Mathematical modeling of dynamics of the number of specimens in a biological population under changing external conditions on the example of the burzyan wild-hive honeybee (Apis mellifera L., 1758). Mathematical Biology end Bioinformatics, 12(1), 224-236. (In Russian). https://doi. org/10.17537/2017.12.224

Korotchenko, I. A., \& Peregrym, M. M. (2009). Crocus reticulatus Steven ex Adams. In Y. P. Didukh (Ed.), Red Book of Ukraine. Plant Kingdom (p. 121). Kyiv: Globalconsulting. (In Ukrainian)

Krivoruchko, T. V. (2006). Morphological indicators of population's Crocus reticulatus Stev. ex Adam. on the territory of Poltava region. Collection of Scientific Works of Poltava State Pedagogical University V.G. Korolenko. Series "Ecology. Biological sciences", 5(52), 151-159. (In Ukrainian)
Krivoruchko, T. V. (2008). Rare steppe ephemeroids of the Left Bank Dnieper region (state of populations and scientific bases of protection) [PhD dissertation abstract]. Kyiv. (In Ukrainian)

Kucherevsky, V. V. (2001). Atlas of rare and endangered plants of Dnipropetrovsk region. Kyiv: Phytosociocenter. (In Ukrainian)

Kushnir, N. V. (2014). The state of introduction populations of species of the genus Crocus L. (Iridaceae Juss.) of Ukrainian flora in the conditions of Kyiv. Florology and Phytosozology, 3-4, 89-93. (In Ukrainian)

Kushnir, N. V. (2015). Species of the genus Crocus L. (Iridaceae Juss.) of the flora of Ukraine [PhD dissertation abstract]. Kyiv. (In Ukrainian)

Kushnir, N. V. (2019). Morphological studies of the leaf plate of species of the genus Crocus $L$. of Ukrainian flora. News Biosphere Reser Askania Nova, 21, 187-193. (In Ukrainian). Retrieved from http://askania-nova-zapovidnik.gov. ua/2020/02/21/visti-biosfernogo-zapovidnikaaskaniya-nova-2019/

Lakin, G. F. (1990). Biometrics. Moscow: Higher School. (In Russian)

Ljubisavljević, I., \& Raca, I. (2020). Comparative morphological and leaf anatomical analysis of the species Crocus danubensis and Crocus variegatus (Iridaceae). Biologia, 75, 381-391. https://doi.org/10.2478/s11756-020-00420-2

Mashkovska, S. P. (Ed.). (2015). Catalog of ornamental herbaceous plants of botanical gardens and arboretums of Ukraine: A reference guide. Kyiv. (In Ukrainian). Retrieved from http://nbg.kiev. ua/upload/biblio/katalog.pdf

Melnyk, V. I., Gritsenko, V. V., Kushnir, N. V., \& Nehrash, Y. M. (2018). Modeling of introduction populations as a method of ex situ protection of rare species of plants. Reports of the National Academy of Sciences of Ukraine, 8, 9197. (In Ukrainian). https://doi.org/10.15407/ dopovidi2018.08.091

Melnyk, V.I., Shynder, O.I., \& Didenko, S.Y. (2010). New locations of rare species for the flora of the Dnieper Upland. Ukrainian Botanical Journal, 67(3), 425-431. (In Ukrainian)

Orlova, L. D., \& Boboshko, O. P. (2012). Biomorphological features of Crocus reticulatus Steven ex Adams in vicinity of Krahmiltsi village (Poltavska oblast). Modern Phytomorphology, 2, 141-144. (In Ukrainian). https://doi.org/10.5281/ zenodo.162627

Ostapko, V. M. (2001). Rare floro fund of the southeast of Ukraine (chorology). Donetsk: Lebed. (In Russian) 
Pavlova, M. A., \& Kachur, L. Y. (2012). Outcomes of species from Crocus L. genus introduction in the Donetsk Botanical Garden of the National Academy of Sciences of Ukraine. Problems of Ecology and Nature Protection of the Technogenic Regions, 1(12), 102-107. (In Russian). Retrieved from http://repo. donnu.ru:8080/jspui/handle/123456789/3663

Peregrym, M. M. (2004). Crocus reticulatus Stev. ex Adam. in Donetsk Upland. Plant Introduction, 24, 21-27. (In Ukrainian). https://doi.org/10.5281/zenodo.3252490

Prokudin, Y. N. (Ed.). (1987). Key to higher plants of Ukraine. Kyiv: Naukova Dumka. (In Russian)

Rassadina, E. V., \& Antonova, J. A. (2015). Ecology of populations and communities. Ulyanovsk: Ulyanovsk State University. (In Russian)

Ricklefs, R. (1979). Fundamentals of general ecology. Moscow: Mir. (In Russian)

Shilova, I. V., Petrova, N. A., Lavrentyev, M. V., \& Bogoslov, A. V. (2019). To the distribution of Crocus reticulatus in the Voronezh region. Bulletin of the Botanical Garden of Saratov State University, 17(2-3), 179-181. (In Russian). https://doi. org/10.18500/1682-1637-2019-2-3-179-181
Shynder, O. I. (2009). Distribution and conditions of populations of Crocus reticulatus Stev. ex Adams (Iridaceae) and Tulipa quercetorum Klok. \& Zoz (Liliaceae) in Eastern Podolia. Ukrainian Botanical Journal, 66(4), 489-497. (In Ukrainian)

Shynder, O. I. (2010). Distribution of rare earlyvernal species of the flora of Murafa Tovtrea. Plant Introduction, 45, 10-19. (In Ukrainian). https://doi.org/10.5281/zenodo.2553586

Sobko, V. G., Lebeda, A. F., \& Gritsenko, V. V. (2013). Phytorarities of the steppe zone of Ukraine. Kyiv: Phytosociocenter. (In Ukrainian)

The Plant List. (2020). Retrieved from http://www. theplantlist.org/

Uranov, A. A. (Ed.). (1976). Plant coenopopulations (basic concepts and structure). Moscow: Science. (In Russian)

Vladimirov, D. R., Grigorevskaya, A. Y., Podobed, E. A., Miroshnikova, N. A., \& Paterikina, E. V. (2020). New locations of Crocus reticulatus Steven ex Adams (Iridaceae) in midland of European Russia. Diversity of Plant World, 2(5), 62-67. (In Russian)

\section{Формування інтродукційної ценопопуляції Crocus reticulatus на ботаніко- географічній ділянці “Степи України” Національного ботанічного саду імені М. М. Гришка НАН України}

Вікторія Гриценко

Національний ботанічний сад імені М.М. Гришка НАН України, вул. Тимірязєвська, 1, м. Київ, 01014, Україна; gritsenkoviktoria@gmail.com

Дослідження виконано під час цвітіння Crocus reticulatus у 2002-2020 рр. на ботаніко-географічній ділянці “Степи України" Національного ботанічного саду імені М.М. Гришка НАН України (НБС). Crocus reticulatus було інтродуковано в НБС з природних місцезростань у 2002-2003 рр. Десять генеративних особин було висаджено на площі $2 \mathrm{M}^{2}$. Площа ценопопуляції та кількість особин збільшувались поступово до 2018 р. У 2019-2020рр. відбувся стрімкий приріст площі та кількості особин, однак їхня середня щільність зменшилась. У спектрах вікових станів збільшився відсоток особин прегенеративного віку (ювенільних, імматурних і віргінільних) та зменшився відсоток генеративних особин. Станом на 2020 р. площа інтродукційної ценопопуляції становила 195 м², у її складі налічувалось 175 особин (38 ювенільних, 21 імматурних, 23 віргінільних і 93 генеративних), а середня щільність загалом становила 0,9 особин на $1 \mathrm{~m}^{2}$. Просторове розміщення особин можна охарактеризувати як випадкове та групове. Це пов'язано з переважанням насіннєвого розмноження, мірмеко- та барохорією. Показники площі, кількості та середньої щільності інтродукційної ценопопуляції знаходяться в межах діапазонів відповідних параметрів природних популяцій, однак $\epsilon$ меншими, ніж у популяцій, які були вихідним джерелом інтродукційного матеріалу. За діапазонами варіації кількості особин різних вікових станів і кількості особин з однією і двома або трьома квітками інтродукційна ценопопуляція C. reticulatus ближча до природної популяції на Київському плато. Різні за кольором квітки відмічено як в інтродукційній ценопопуляції, так і в природних популяціях C. reticulatus. 